\title{
Evaluation on Antifungal Property of Supercritical Carbon Dioxide Extract of Prosopis juliflora Leaves against Plant Pathogens
}

\author{
Krishnaveni Magadi ${ }^{1 *}$, Nagaraj Naik², Mahadevswamy ${ }^{1}$, \\ K. Tamil Vendan ${ }^{1}$ and Udaykumar Nidoni ${ }^{1}$
}

${ }^{1}$ Department of Agricultural Microbiology, College of Agriculture, University of Agricultural Sciences, Raichur-584 104, Karnataka, India

${ }^{2}$ Department of Food Processing and Engineering, College of Agriculture, University of Agricultural Sciences, Raichur-584101, Karnataka, India

*Corresponding author

\begin{abstract}
A B S T R A C T
Key words

Prosopis juliflora,

Supercritical fluid

extraction, Antifungal

activity, Food poisoned

technique and per cent of

inhibition

Article Info

Accepted:

04 July 2018

Available Online:

10 August 2018

The aim of this study was to evaluate antifungal property of the Prosopis juliflora leaf extract as a potential natural source for synthesis of new drugs to avoid gaining of antifungal resistance. The Prosopis juliflora leaf extracts obtained by supercritical fluid extraction were assessed for their antifungal property against Rhizoctonia bataticola, Alternaria alternata and Colletotrichum gloeosporioides by food poisoned technique. Prosopis juliflora leaf extract obtained by $\mathrm{SC}_{-} \mathrm{CO}_{2}$ (at $50{ }^{\circ} \mathrm{C}$ and 200 bar) showed strong antifungal activities against the fungal pathogens viz., Rhizoctonia bataticola, Alternaria alternata and Colletotrichum gloeosporioides with 94.07 per cent, 93.15 per cent and 92.43 per cent of inhibition, respectively which indicates that supercritical fluid extract shows best results having per cent of inhibition greater than that of the soxhlet extraction process (55.31, 75.63 and 45.13 per cent of inhibition, respectively). The results of investigation showed that all the extracts had inhibitory effect on the growth of all the isolates. It can be concluded that the Prosopis juliflora could be a potential source for antifungal agents, probably a novel inhibitory metabolite and is potential natural fungicide.
\end{abstract}

\section{Introduction}

Plants are known to be the source of effective and versatile therapeutic agents against various diseases. Records of indigenous knowledge from various parts of the world illustrate an age long tradition of plant being a major bio-resource base for health care (Wamburu et al., 2015). About 70-80 per cent of the world populations, particularly in the developing countries, rely on non- conventional medicine in their primary health care as reported by the World Health Organization. The interest of finding natural bioactive components has increased due to the harmful effects of synthetic fungicides on environment and health. Natural plant products can be alternatives to currently used synthetic pesticides, since they provide unlimited opportunities for the discovery of new pesticides because of their rich bioactive chemical constituents. Scientific interest in 
medicinal plant has burgeoned in recent times due to increased efficiency of new plant derived drugs and rising concerns about the side effects of modern medicine.

Prosopis juliflora is a shrub or small tree in the family Fabaceae. It has established itself as a weed, notably in Asia and Australia (Santos et al., 2013). Prosopis juliflora DC., mesquite tree is one of the major invasive alien species of India and it has been used to treat eye problems, open wounds, dermatological ailments and digestive problems by the native tribes of many countries. It has soothing, astringent, antiseptic, antibacterial and antifungal properties. The extracts of $P$. juliflora seeds and leaves were well studied for several in vitro pharmacological effects such as antibacterial, antifungal and antiinflammatory properties.

The plant has been reported to treat oral ailments like toothache. The leaves were used against asthma, bronchitis, conjunctivitis as well as against skin diseases, blood and venereal diseases and acts as an insecticide.

Prosopis juliflora has been used for its pesticidal properties. Extract from P. juliflora has shown its antifungal potential against Aspergillus isolated from sorghum, maize and paddy samples. For economic and eco-friendly disease management aqueous leaf extracts of $P$. juliflora and L. esculentum were used, which completely inhibited the in vitro germination of $P$. personata and $P$. arachidis.

There are a number of conventional extraction methods for Prosopis juliflora. Solvent extraction is being practiced for extraction from Prosopis juliflora leaves. However, this method has the major disadvantage of solvent residue in the extracts. In the field of natural products, the new technique of Supercritical Fluid Extraction (SFE) has gained increasing attention over the traditional techniques in the recovery of edible and essential oils, it does not have any of the negative effects related to traditional organic solvents, at optimal conditions (Casas et al., 2009).

To date, any research article on supercritical fluid extraction of Prosopis juliflora leaves has not been reported. Keeping in view of these facts, the investigation on "Evaluation on antifungal property of supercritical carbon dioxide extract of Prosopis juliflora leaves against plant pathogens" was undertaken in the Department of Agricultural Microbiology, College of Agriculture, University of Agricultural Sciences, Raichur, Karnataka (India).

\section{Materials and Methods}

\section{Raw materials}

Clean and matured leaves of Prosopis juliflora were collected around the UAS campus, Raichur. Then the leaves were cut dried in dehumidified air dryer (make: Bry Air Asia; model: FSD-600) at $45{ }^{\circ} \mathrm{C}$ and $15 \% \mathrm{RH}$. The dried leaves were ground in laboratory hammer mill with $\mathrm{LN}_{2}$ cooling to obtain fine powder (Sankalpa et al., 2014). The solvents, chemicals and reagents (analytical grade) used throughout the experiment were procured from M/s. Sigma Aldrich Chemicals, Bangalore (Karnataka).

\section{Fungal culture}

Authentic pure culture of Colletotrichum gloeosporioides were obtained from Microbial Type Culture Collection Centre [MTCC] Institute of Microbial Technology [IMTECH] Chandigarh in lyophilized vial. Whereas Alternaria alternata and Rhizoctonia bataticola were collected from Department of Plant Pathology, UAS, Raichur. Procured cultures were maintained in appropriate media for further use. 


\section{Extraction of Prosopis juliflora leaf extract}

The supercritical carbon dioxide extraction system (Thar; SFE 500 system) was used for extraction of Prosopis juliflora leaf powder. Deionized water (at $5{ }^{\circ} \mathrm{C}$ ) was used for cooling different zones in the $\mathrm{SC}-\mathrm{CO}_{2}$ extraction system. The independent variables selected for the study were supercritical fluid $\left(\mathrm{SC}-\mathrm{CO}_{2}\right)$ pressures of 100,150 and $200 \mathrm{bar}$ and temperatures of 40,50 and $60{ }^{\circ} \mathrm{C}$ at constant dynamic extraction time of $90 \mathrm{~min}$ (Liza., 2010) Table 1.

Hundred grams of Prosopis juliflora leaf powder was placed into the extractor vessel. The flow rates of supercritical $\mathrm{CO}_{2}$ and cosolvent (ethanol) were maintained at 20 and 2 g/min, respectively (Pradhan et al., 2010). Static extraction process was performed for 30 min (Palafox et al., 2012). After attaining desired pressure and temperature dynamic extraction time $(90 \mathrm{~min})$ was started by opening the exit valve of the $\mathrm{SC}-\mathrm{CO}_{2}$ extraction system.

The static extraction time allowed the sample to soak in the $\mathrm{CO}_{2}$ and co-solvent in order to equilibrate the mixture at desired pressure and temperature. During the dynamic extraction time, $\mathrm{CO}_{2}$ carrying the crude extract flowed out of the extraction vessel and then into a collection vessel, where the $\mathrm{CO}_{2}$ was separated through the vent connected to the fume hood.

Prosopis juliflora leaves extraction was carried out by soxhlet extraction method using SOCS- PLUS apparatus (Make: Pelican Equipments; Model: SCS-08) with hexane as solvent. Accurately, $100 \mathrm{~g}$ of the Prosopis juliflora leaf powder was taken into the thimble and placed it in the sample compartment of the extractor. Sample compartment was attached to a $500 \mathrm{ml}$ round bottom flask containing 300-350 $\mathrm{ml}$ hexane.
SOCS- PLUS set-up was assembled and heated in a mantle. The SOCS- PLUS apparatus was run at $85{ }^{\circ} \mathrm{C}$ for $90 \mathrm{~min}$. Hexane in the oil extract was distilled out by using a rotary flash vacuum evaporator (Superfit, Rotavap; PBU-6D) (Malapit, 2010). Extraction process of Prosopis juliflora leaf extract was standardized based on the extraction yield and extraction efficiency.

\section{In vitro screening of antifungal activity $\mathrm{SC}$ - $\mathrm{CO}_{2}$ extracted Prosopis juliflora leaf extract by food poison technique}

Food Poison technique described by Nene and Thapliyal (1993) demonstrated by Prasad and Anamika (2015) was employed to test antifungal effect. Petri plates were washed, rinsed with sterile distilled water, dried, wrapped in tin foil and kept in autoclave at 100 ${ }^{\circ} \mathrm{C}$ for 15 min to sterilize.

The potato dextrose media was prepared and sterilized. A volume of $0.5 \mathrm{ml}$ of plant extract was aseptically poured into Petri plate followed by addition of $9.5 \mathrm{ml}$ of melted PDA and was gently mixed. One inoculum disc of test fungus was aseptically inoculated upside down at the centre of the Petri plate and incubated at $25^{\circ} \mathrm{C}$.

The media plate without extract set as a control. The average radial growth of the fungal mycelial was measured on the $7^{\text {th }}$ day of incubation.

Mycelial inhibition $(\%)=\frac{\text { DC }- \text { DT }}{D C} \times 100$

Where,

DC - Average diameter of colony in control plate

DT - Average diameter of colony in treatment plate 


\section{Results and Discussion}

Effect of SC-CO 2 temperature and pressure on extraction efficiency of Prosopis juliflora leaf extract

The effect of $\mathrm{SC}-\mathrm{CO}_{2}$ temperature and pressure on extraction efficiency of Prosopis juliflora leaf extract at three levels namely 40 , 50 and $60{ }^{\circ} \mathrm{C}$ and 100, 150 and 200 bar are presented in Table 1. It is evident from the figure that as pressure increased from 100 to 200 bar, the extraction efficiency increased. This might be due to the fact that the increase in pressure increased the density of the $\mathrm{CO}_{2}$ thereby increasing the solvent strength and solubility of the oil in $\mathrm{CO}_{2}$ (Liza et al., 2010). The highest extraction efficiency of 93.37 per cent were recorded at $\mathrm{SC}-\mathrm{CO}_{2}$ pressure of 200 bar, temperature of $50{ }^{\circ} \mathrm{C}$ which was considered as the optimum and best $\mathrm{SC}-\mathrm{CO}_{2}$ extraction condition for obtaining the highest extraction efficiency from Prosopis juliflora leaf powder.

The lowest of 55.62 per cent were recorded at $\mathrm{SC}-\mathrm{CO}_{2}$ pressure of $100 \mathrm{bar}$, temperature of $40{ }^{\circ} \mathrm{C}$. The extraction efficiency decreased with the rise of temperature at low pressures, due to the reduced density of $\mathrm{CO}_{2}$ with increased temperature (Zhao and Zhang, 2013).

In vitro screening of $\mathrm{SC}-\mathrm{CO}_{2}$ extracted Prosopis juliflora leaf extract for antifungal activity

The antifungal activity of $\mathrm{SC}-\mathrm{CO}_{2}$ extracted Prosopis juliflora leaf extract at different temperature and pressure combinations against the plant pathogens are presented in Table 2. Among the different treatments of $\mathrm{SC}-\mathrm{CO}_{2}$ extracted Prosopis juliflora leaf extract, all the treatments showed significant antifungal activity against all the three fungal pathogens tested.
From the Table 3, it is observed that the percent of inhibition of extract were in the range of 55.31 per cent to 94.07 per cent for Rhizoctonia bataticola, 75.63 per cent to 93.15 per cent for Alternaria alternata, and 46.40 per cent to 92.43 per cent for Colletotrichum gloeosporioides.

The highest zone of inhibition for Rhizoctonia bataticola of 94.07 per cent was found at 200 bar and $50{ }^{\circ} \mathrm{C}$ treatment and lowest of 55.31 per cent was found in soxhlet extraction. The highest zone of inhibition for Alternaria alternata of 93.15 per cent was found at 200 bar and $50{ }^{\circ} \mathrm{C}$ treatment and lowest of 75.63 per cent was found in soxhlet extraction.

The highest zone of inhibition for Colletotrichum gloeosporioides of 92.43 per cent was found at 200 bar and $50{ }^{\circ} \mathrm{C}$ treatment and lowest of 55.67 per cent was found in soxhlet extraction. Effect of Prosopis juliflora leaf extract by supercritical fluid extraction against Rhizoctonia bataticola, Alternaria alternata, and Colletotrichum gloeosporioides was shown in Plate 1, Plate 2 and Plate 3, respectively.

Results of present investigation were in agreement with Raghavendra et al., (2009) that the activity of aqueous extract of Prosopis juliflora against Alternaria alternata showed 71.59 per cent inhibition of mycelial growth. Ikram and Dawar (2013) studied on Prosopis juliflora leaf, stem and flower powder as a soil amendment carried to control of Rhizactonia solani in cowpea and mung bean. Deressa et al., (2015) used methanol, acetone and aqueous extract of Prosopis juliflora leaves against Colletotrichum gloeosporioides the results showed radial growth inhibition of 100 per cent, 100 per cent, 79.60 per cent, respectively. Bazie et al., (2014) reported the activity of methanolic extract of Prosopis juliflora against Colletotrichum musae, which showed $30.70 \mathrm{~mm}$ zone of inhibition. 
Table.1 Treatment combinations for supercritical fluid extraction of Prosopis juliflora leaf extract

\begin{tabular}{|c|c|c|}
\hline Treatment & Temperature ${ }^{\circ} \mathbf{C}$ & Pressure(bar) \\
\hline $\mathbf{T}_{\mathbf{1}}$ & 40 & 100 \\
\hline $\mathbf{T}_{\mathbf{2}}$ & 40 & 150 \\
\hline $\mathbf{T}_{\mathbf{3}}$ & 40 & 200 \\
\hline $\mathbf{T}_{\mathbf{4}}$ & 50 & 100 \\
\hline $\mathbf{T}_{\mathbf{5}}$ & 50 & 150 \\
\hline $\mathbf{T}_{\mathbf{6}}$ & 50 & 200 \\
\hline $\mathbf{T}_{\mathbf{7}}$ & 60 & 100 \\
\hline $\mathbf{T}_{\mathbf{8}}$ & 60 & 150 \\
\hline $\mathbf{T}_{\mathbf{9}}$ & 60 & 200 \\
\hline $\mathbf{T}_{\mathbf{1 0}}$ & Soxhlet Extraction (Conventional method) \\
\hline
\end{tabular}

$\mathrm{T}_{10}=$ Control - Soxhlet extraction carried out at $85^{\circ} \mathrm{C}$ for 90 minutes

Table.2 Effect of $\mathrm{SC}-\mathrm{CO}_{2}$ temperature and pressure on extraction yield and extraction efficiency of Prosopis juliflora leaf extract

\begin{tabular}{|c|c|c|}
\hline Treatments & $\begin{array}{c}\text { Extraction } \\
\text { yield }(\mathrm{g} / 100 \mathrm{~g})\end{array}$ & $\begin{array}{c}\text { Extraction } \\
\text { efficiency }(\%)\end{array}$ \\
\hline$T_{1}$ & $8.40^{\mathrm{f}}$ & $55.62^{f}$ \\
\hline $\mathbf{T}_{2}$ & $9.15^{\mathrm{e}}$ & $60.59^{e}$ \\
\hline$T_{3}$ & $12.00^{c}$ & $79.46^{c}$ \\
\hline $\mathbf{T}_{4}$ & $9.80^{d}$ & $64.89^{d}$ \\
\hline $\mathbf{T}_{5}$ & $12.60^{b}$ & $83.44^{b}$ \\
\hline$T_{6}$ & $14.10^{\mathrm{a}}$ & $93.37^{\mathrm{a}}$ \\
\hline$T_{7}$ & $8.60^{f}$ & $57.17^{\mathrm{f}}$ \\
\hline $\mathbf{T}_{8}$ & $9.74^{\mathrm{d}}$ & $64.67^{d}$ \\
\hline$T_{9}$ & $12.70^{\mathrm{b}}$ & $84.10^{\mathrm{b}}$ \\
\hline $\mathbf{T}_{10}$ & $9.25^{\mathrm{e}}$ & $61.25^{\mathrm{e}}$ \\
\hline Mean & 10.64 & 70.49 \\
\hline SEm \pm & 0.070 & 0.440 \\
\hline CD (1\%) & 0.210 & 1.318 \\
\hline
\end{tabular}

Note: Mean values followed by same superscript letters are not significantly different 
Table.3 Antifungal activity of Prosopis juliflora leaf extract obtained by supercritical fluid extraction Method against fungal test organisms

\begin{tabular}{|c|c|c|c|c|c|c|}
\hline \multirow[t]{2}{*}{ Treatments } & \multicolumn{2}{|c|}{ Rhizoctonia bataticola } & \multicolumn{2}{|c|}{ Alternaria alternata } & \multicolumn{2}{|c|}{ Colletotrichum gloeosporioides } \\
\hline & $\begin{array}{c}\text { Mycelia growth } \\
\text { (mm) }\end{array}$ & $\begin{array}{c}\text { Inhibition } \\
(\%)\end{array}$ & $\begin{array}{l}\text { Mycelia growth } \\
\text { (mm) }\end{array}$ & $\begin{array}{c}\text { Inhibition } \\
(\%)\end{array}$ & $\begin{array}{l}\text { Mycelia growth } \\
(\mathbf{m m})\end{array}$ & $\begin{array}{c}\text { Inhibition } \\
(\%)\end{array}$ \\
\hline $\mathbf{T}_{1}$ & 21.40 & $76.04^{\mathrm{de}}$ & 21.50 & $76.65^{\mathrm{i}}$ & 32.10 & $61.74^{\mathrm{g}}$ \\
\hline $\mathbf{T}_{2}$ & 20.50 & $75.24^{\mathrm{e}}$ & 18.50 & $80.05^{\mathrm{gh}}$ & 30.10 & $64.15^{f}$ \\
\hline $\mathbf{T}_{3}$ & 19.50 & $78.06^{\mathrm{cd}}$ & 10.60 & $87.87^{d}$ & 24.70 & $70.72^{d}$ \\
\hline $\mathbf{T}_{4}$ & 25.30 & $71.66^{f}$ & 19.20 & $78.82^{h}$ & 28.43 & $66.18^{\mathrm{e}}$ \\
\hline $\mathbf{T}_{5}$ & 17.30 & $80.96^{b}$ & 13.20 & $89.40^{\mathrm{c}}$ & 14.13 & $83.36^{c}$ \\
\hline $\mathrm{T}_{6}$ & 5.30 & $94.07^{\mathrm{a}}$ & 6.10 & $93.15^{b}$ & 6.37 & $92.43^{b}$ \\
\hline $\mathbf{T}_{7}$ & 35.20 & $61.00^{\mathrm{g}}$ & 16.50 & $81.12^{\mathrm{g}}$ & 37.20 & $55.67^{\mathrm{i}}$ \\
\hline $\mathrm{T}_{8}$ & 27.20 & $69.70^{f}$ & 15.20 & $82.98^{\mathrm{f}}$ & 34.30 & $59.26^{\mathrm{h}}$ \\
\hline $\mathbf{T}_{9}$ & 18.10 & $79.58^{\mathrm{bc}}$ & 13.30 & $85.07^{\mathrm{e}}$ & 28.13 & $66.57^{\mathrm{e}}$ \\
\hline $\mathbf{T}_{10}$ & 40.50 & $55.31^{\mathrm{h}}$ & 22.50 & $75.63^{i}$ & 45.13 & $46.40^{\mathrm{j}}$ \\
\hline Negative control & 90 & Nil & 90 & Nil & 84 & Nil \\
\hline Positive control & 5 & $94.6^{\mathrm{a}}$ & 4.9 & $94.57^{\mathrm{a}}$ & 5.1 & $93.77^{\mathrm{a}}$ \\
\hline Mean* & 26.69 & 69.69 & 20.55 & 77.11 & 30.38 & 63.35 \\
\hline Sem & 0.115 & 0.555 & 0.097 & 0.283 & 0.187 & 0.157 \\
\hline CD1\% & 0.457 & 2.195 & 0.384 & 1.119 & 0.739 & 0.620 \\
\hline
\end{tabular}

Note: Mean values followed by same superscript letters are not significantly different. 
Plate.1 Effect of Prosopis juliflora leaf extract obtained by supercritical fluid extraction method against Rhizoctonia bataticola

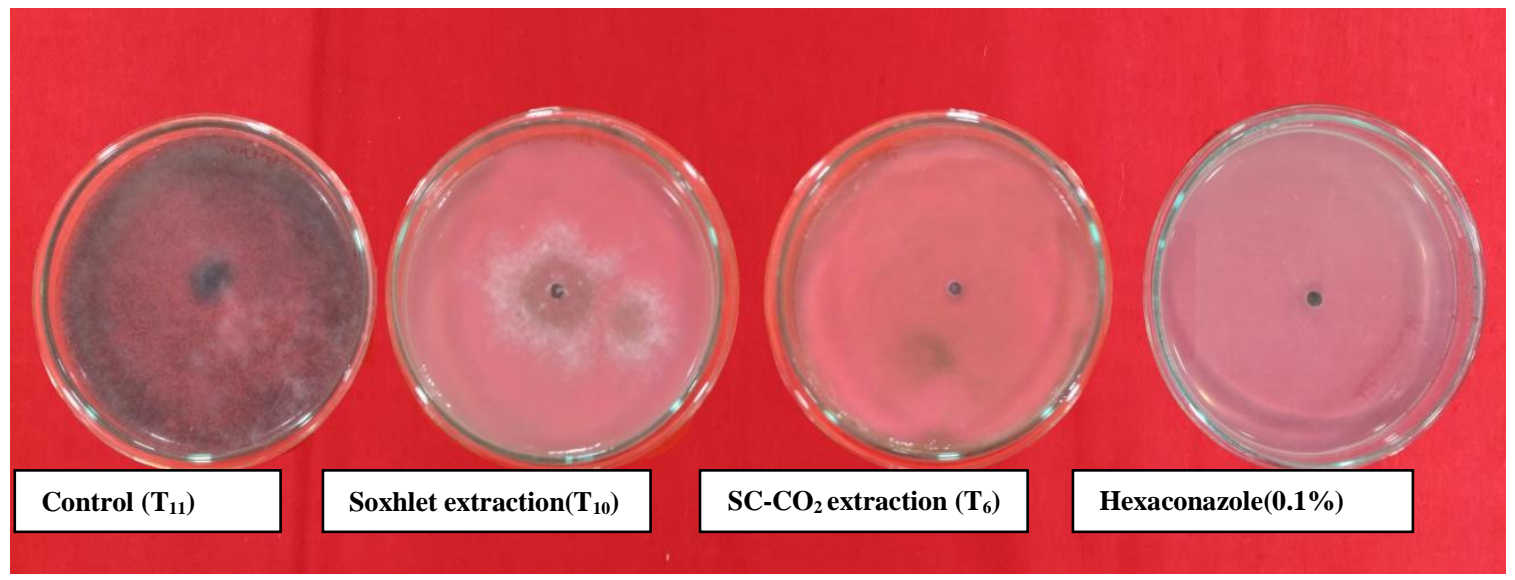

Plate.2 Effect of Prosopis juliflora leaf extract obtained by supercritical fluid extraction method against Alternaria alternate

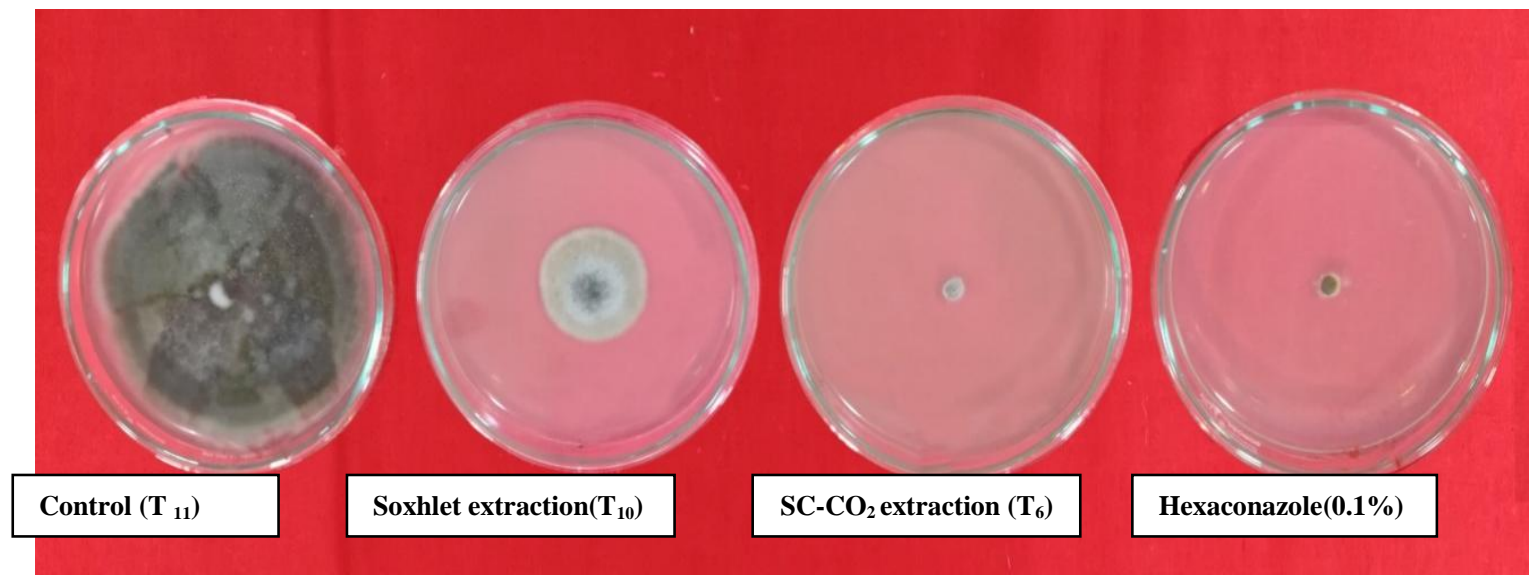

Plate.3 Effect of Prosopis juliflora leaf extract obtained by supercritical fluid extraction method against Colletotrichum gloeosporioides

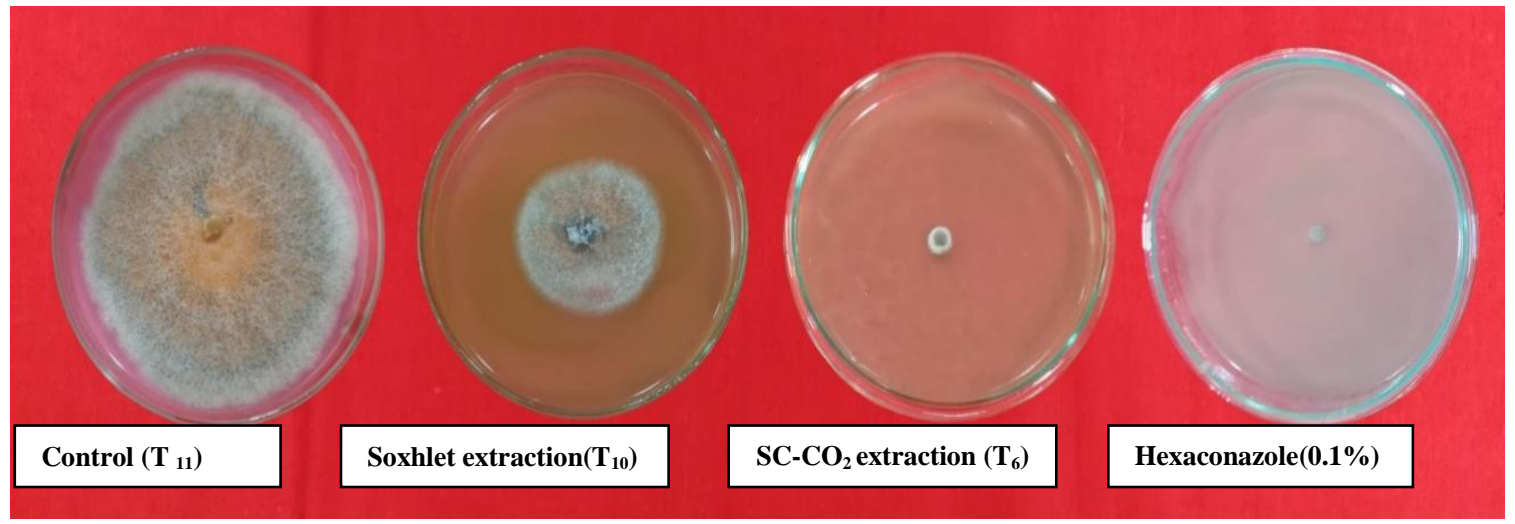


Prosopis juliflora showed notable antifungal activity and it can be used to discover bioactive natural products that may serve as leads for the development of new pharmaceuticals that address hither unmet therapeutic needs. The results support the idea that Prosopis juliflora plant extracts could be used as a promising source of potential antifungal agents and can be used in medicinal applications. The results obtained from the above conducted study provide evidence for the presence of antimicrobial bio active compounds in Prosopis juliflora leaf extract. These compounds can degrade the cell wall, disrupt the cytoplasmic membrane, damage membrane proteins and interference with active transport of metabolic enzymes, or dissipation of cellular energy in ATP form (Davidson, 2001), which may eventually lead to cell death. More elaborative study in this plant with its pure compounds may lead to the development of natural antioxidant and alternative antifungal agents of against plant pathogens.

\section{Acknowledgement}

Authors are thankful to the Head, Department of Agricultural Microbiology, Head, PRFQAL Lab and Department of Food Processing and Engineering, University of Agriculture sciences, Raichur for providing the necessary facilities in accomplishing the research work.

\section{References}

Bazie, S., Amare, A. and Woldetsadik, K., 2014, Antifungal activity of some plant extracts against (Colletotrichum musae) the cause of postharvest banana anthracnose. J. Plant Pathol. Microb., 5(2): 2157-7471.

Casas, L., Mantell, C., Rodriguez, M., Torres, A., Macias, F. A. and Ossa, M. E., 2009, Extraction of natural compounds with biological activity from sunflower leaves using supercritical carbon dioxide. J. Chem. Engg, 152(1): 301306.

Davidson, P. M., 2001, Chemical preservatives and natural antimicrobial compounds. Food Microbiology: Fundamentals and Frontiers, ASM Press, Washington, 593-627.

Deressaa, T., Lemessab, F. and Wakjirab, M., 2015, Antifungal activity of some invasive alien plant leaf extracts against mango (Mangifera indica) anthracnose caused by Colletotrichum gloeosporioides. Int. J. Pest Manage., 61(2): 99-105.

Ikram N. and Dawar, S., 2013, Effect of Prosopis juliflora (sw.) Dc. in the control of root rot fungi of Cowpea (Vigna unguiculata L.) and mung bean (Vigna radiata (L.) Wilczek). Pakistan J. Bot., 45(2): 649-654.

Liza, M. S., Abdul, R. R., Mandana, B., Jinap, S., Rahmat A., Zaidul, I. S. M. and Hamid, A., 2010, Supercritical carbon dioxide extraction of bioactive flavonoid from Strobilanthes crispus (Pecah Kaca). J. Food Bioprod. Process., 88: 319-326.

Malapit, C. A. (2010). Report on the extraction of moringa oil from moringa oil seeds. J. Lipid. Sci, 1(1): 1-5.

Nene, Y. L. and Thapliyal, P. N., 1993, Evaluation of fungicides in fungicides in plant diseases control. New Delhi: Oxford and INH publishing Co. pvt. Ltd.

Palafox, J. O., Navarrete, A., Julio, C., Rivero, S., Atoche, C. R., Escoffie, J., Antonio, P. A. and Uribe, R., 2012, Extraction and characterization of oil from Moringa oleifera using supercritical $\mathrm{CO}_{2}$ and traditional solvents. American J. Analytical.Chemi, 3(1): 946-949. 
Palafox, J. O., Navarrete, A., Julio, C., Rivero, S., Atoche, C. R., Escoffie, J., Antonio, P. A. and Uribe, R., 2012, Extraction and characterization of oil from Moringa oleifera using supercritical $\mathrm{CO}_{2}$ and traditional solvents. American J. Analytical.Chemi, 3(1): 946-949.

Pradhan, R. C. A., Meda, P. K. A., Rout, B. V., Naik, S. A., Ajay. K. and Dalai, C., 2010, Supercritical $\mathrm{CO}_{2}$ extraction of fatty oil from flaxseed and comparison with screw press expression and solvent extraction processes. J. Fd. Engg, 98(1): 393-397.

Prasad, R. R. and Anamika, 2015, Effects of plant leaf extract against Colletotrichum gloeosporioides (Penz) Sac. causing post-harvest disease of papaya. J. Agric. Sci., 7(5): 1916-9752.

Raghavendra, M. P., Satish, S. and Raveesha, K. A., 2009, Alkaloids isolated from leaves of Prosopis juliflora against Xanthomonas pathovars, Arch.
Phytopathol. Plant Protec., 42(11): 1033-1041.

Santos, T. D. Pereira, A., Flavia, G., Silva, P. G. D., Neta, Geris, R., Martins, D., Euzébio G. Santana, D., Cláudio, L., Freitas, Mauro, P., and Batista, R., 2013, Antibacterial activity of the alkaloid-enriched extract from Prosopis juliflora pods and its influence on in vitro ruminal digestion edilene. Int. J. Mol. Sci., 14: 8496-8516.

Wamburu, R. W., Kareru, P. G., Mbaria, J. M., Nyaya, G. and Rechab, S. O., 2015, spectrometric detection of organic compounds and toxicity of ethanolic leaves extracts of Prosopis juliflora. Chem. Material Res., 7(1): 2224-3224.

Zhao, S. and Zhang, D., 2013, A parametric study of supercritical carbon dioxide extraction of oil from Moringa oleifera seeds using a response surface methodology. J. Separation and Purification Technol., 113(5): 9-17.

\section{How to cite this article:}

Krishnaveni Magadi, Nagaraj Naik, Mahadevswamy, K. Tamil Vendan and Udaykumar Nidoni. 2018. Evaluation on Antifungal Property of Supercritical Carbon Dioxide Extract of Prosopis juliflora Leaves against Plant Pathogens. Int.J.Curr.Microbiol.App.Sci. 7(08): 1-9. doi: https://doi.org/10.20546/ijcmas.2018.708.001 